Article

\title{
Measuring the Changes of Greenhouse Gas Emissions Caused by the Trans-Pacific Partnership
}

\author{
Hirokazu Akahori ${ }^{1, *}$, Daisuke Sawauchi ${ }^{2}$ and Yasutaka Yamamoto ${ }^{2}$ \\ 1 Faculty of Bioresource Sciences, Akita Prefectural University, Akita 010-0195, Japan \\ 2 Research Faculty of Agriculture, Hokkaido University, Sapporo 060-8589, Japan; \\ dsawa@agecon.agr.hokudai.ac.jp (D.S.); yamay@agecon.agr.hokudai.ac.jp (Y.Y.) \\ * Correspondence: akahori@akita-pu.ac.jp; Tel.: +81-185-45-3946 \\ Academic Editor: Ernest Reig-Martínez \\ Received: 10 February 2017; Accepted: 25 April 2017; Published: 29 April 2017
}

\begin{abstract}
The Trans-Pacific Partnership (TPP) is one of the proposed mega-free trade agreements. While several previous studies have measured the economic impact of the trade liberalization resulting from the TPP, the TPP may have not only a very large economic impact, but also a significant environmental impact, such as changes in greenhouse gas (GHG) emissions. The purpose of this paper is to contribute to the debate over TPP and GHG emissions by asking the following question: Will the TPP increase or decrease GHG emissions? We estimate the potential impact on GHG emissions changes caused by the TPP using the Global Trade Analysis Project (GTAP) model, and the GTAP $\mathrm{CO}_{2}$ and non- $\mathrm{CO}_{2}$ emissions databases. Our results suggest that the TPP is likely to increase the total amount of GHG emissions in the 12 TPP member countries, as well as global emissions. The main reason for increasing TPP member and global GHG emissions is non- $\mathrm{CO}_{2}$ emissions growth in Australia and the US.
\end{abstract}

Keywords: Trans-Pacific Partnership; greenhouse gas; Global Trade Analysis Project

\section{Introduction}

The Trans-Pacific Partnership (TPP) was signed by 12 countries (Japan, Malaysia, Singapore, Vietnam, Brunei, Australia, New Zealand, the United States (US), Canada, Mexico, Peru, and Chile) on February 2016. The current TPP members account for approximately 40 percent of global GDP and one third of world trade [1]. Compared with the other Asia-Pacific mega-free trade agreements (FTAs) (Regional Comprehensive Economic Partnership (RCEP), Free Trade Area of Asia-Pacific (FTAAP), and Japan-China-Korea FTA (JCKFTA)), the TPP is characterized by not including the large Asian countries, China and India. The formation of a TPP would have both a very large economic impact and a significant environmental impact for the TPP members and the world. The environmental impact of a regional trade agreement is an empirical question [2].

The purpose of this paper is to contribute to the debate over the TPP and greenhouse gas (GHG) emissions by asking the following question: Does the TPP increase or decrease GHG emissions? To address this research question, we estimate the potential impact on GHG emissions changes of the TPP using the Global Trade Analysis Project (GTAP) model [3], the $\mathrm{GTAP} \mathrm{CO}_{2}$ emissions database [4], and the GTAP non- $\mathrm{CO}_{2}$ emissions database [5].

\section{Literature Review}

Several previous studies have quantitatively analyzed the economic impact of the TPP (Table 1). Burfisher et al. [6] assessed the impact of the TPP on agriculture using the static GTAP model and GTAP 8 database, and the model was solved with macroprojections and trade policy updates to 2025. They 
showed that the impact on real GDP is quite small, and that total agricultural exports and imports will increase for all TPP members. Farm sector outputs decrease in Japan and increase in Australia, New Zealand, and the US. Cheong [7] used the recursive dynamic GTAP model and GTAP 8 database. The results showed that country-level changes in 2027 GDP compared with the baseline range from $-0.13 \%$ (Chile) to $0.97 \%$ (New Zealand). Kawasaki [8] used the static GTAP Computable General Equilibrium (CGE) model with capital accumulation and endogenous productivity growth and the GTAP 8 database updated to 2010. They showed that changes in welfare associated with tariff removal as a percentage of real GDP range from $0.1 \%$ (US) to $9.9 \%$ (Vietnam). Itakura and Lee [9] used the recursive dynamic GTAP model and GTAP 7 database. They showed that changes in 2030 welfare compared with the baseline range from $0.8 \%$ (US) to $5.6 \%$ (Vietnam). Lee and Itakura [10] used the recursive dynamic GTAP model and GTAP 8.1 database. They showed that changes in 2030 welfare compared with the baseline range from $0.15 \%$ (US) to $2.66 \%$ (Vietnam), and that Japan's livestock-sector output decreases by $6.1 \%$. Petri et al. [11] used the recursive dynamic CGE model with Melitz firm heterogeneity, foreign direct investment flows, and preliminary GTAP 8 database. They showed that changes in 2025 GDP compared with the baseline range from $0.4 \%$ (US) to $13.6 \%$ (Vietnam) and that changes in 2025 exports range from $2.5 \%$ (Chile) to $37.3 \%$ (Vietnam). Areerat et al. [12] used the static GTAP model and GTAP 7 database. They showed that changes in GDP range from $-0.03 \%$ (Peru) to $0.49 \%$ (Vietnam).

Table 1. Previous studies.

\begin{tabular}{|c|c|c|c|}
\hline Authors & Type of CGE Model & TPP Scenario & Results \\
\hline Cheong [7] & $\begin{array}{l}\text { Recursive dynamic GTAP } \\
\text { model, solved over 2013-27 } \\
\text { baseline, V8 (2007) GTAP } \\
\text { database }\end{array}$ & Tariff elimination & $\begin{array}{l}\text { Changes in } 2027 \text { GDP compared } \\
\text { with baseline range from }-0.13 \% \\
\text { (Chile) to } 0.97 \% \text { (New Zealand). }\end{array}$ \\
\hline Kawasaki [8] & $\begin{array}{l}\text { Static GTAP CGE model with } \\
\text { capital accumulation and } \\
\text { endogenous productivity } \\
\text { growth, V8 (2007) GTAP } \\
\text { database updated to } 2010\end{array}$ & $\begin{array}{l}\text { Tariff elimination and } 50 \\
\text { percent reduction in NTBs on } \\
\text { preferred partners and } 25 \\
\text { percent NTB reduction on rest } \\
\text { of world }\end{array}$ & $\begin{array}{l}\text { Changes in welfare as percent of } \\
\text { real GDP range from } 0.1 \% \text { (US) to } \\
9.9 \% \text { (Vietnam) with tariff } \\
\text { removal; with tariff and NTB } \\
\text { removal, range from } 0.8 \% \text { (US) to } \\
20.6 \% \text { (Malaysia). }\end{array}$ \\
\hline Itakura and Lee [9] & $\begin{array}{l}\text { Recursive dynamic GTAP, } \\
\text { solved over 2004-30, V7 (2004) } \\
\text { GTAP database }\end{array}$ & $\begin{array}{l}\text { Tariff elimination and } 25 \\
\text { percent reduction in NTBs, } \\
\text { includes TPP plus an East } \\
\text { Asian and an Asia-Pacific } \\
\text { trade area (TPP includes South } \\
\text { Korea) }\end{array}$ & $\begin{array}{l}\text { Changes in } 2030 \text { welfare } \\
\text { compared with baseline range } \\
\text { from } 0.8 \% \text { (US) to } 5.6 \% \text { (Vietnam). }\end{array}$ \\
\hline Lee and Itakura [10] & $\begin{array}{l}\text { Recursive dynamic GTAP, } \\
\text { solved over 2007-30, V8.1 } \\
\text { (2007) GTAP database }\end{array}$ & $\begin{array}{l}\text { Tariff elimination and } 20 \\
\text { percent reduction in NTBs, } \\
\text { rice is excluded from tariff } \\
\text { elimination, includes RCEP, } \\
\text { enlarged TPP, and TPP plus } \\
\text { FTAAP scenario }\end{array}$ & $\begin{array}{l}\text { Changes in } 2030 \text { welfare } \\
\text { compared with baseline range } \\
\text { from } 0.15 \% \text { (US) to } 2.66 \% \\
\text { (Vietnam). Japan's farm sector } \\
\text { outputs decrease. }\end{array}$ \\
\hline Areerat et al. [12] & $\begin{array}{l}\text { Static GTAP model, V7 (2004) } \\
\text { GTAP database }\end{array}$ & $\begin{array}{l}\text { Tariff elimination (TPP does } \\
\text { not include Malaysia, Mexico } \\
\text { and Canada) }\end{array}$ & $\begin{array}{l}\text { Change in GDP range from } \\
-0.03 \% \text { (Peru) to } 0.49 \% \text { (Vietnam) } \\
\text { (TPP }+\mathrm{J} \text { scenario). }\end{array}$ \\
\hline
\end{tabular}

Note: Source: Burfisher et al. [6]. This table is adjusted to include Lee and Itakura [10] and to amend Table 14 in Burfisher et al. [6]. 
Several previous studies have analyzed the environmental impact of trade liberalization on GHG emissions (e.g., Thomassin and Mukhopadhyay [2]; Gumilang et al. [13]; Liu et al. [14]; Mukhopadhyay and Thomassin [15]; Saunders et al. [16]; Verburg et al. [17]; and Akahori and Yamamoto [18,19]). Akahori and Yamamoto $[18,19]$ assessed the impact of the RCEP and the FTAAP on GHG emissions, respectively. However, no studies have examined the environmental impact on GHG emissions caused by the TPP.

\section{Methods and Data}

To compare our results with those of other studies of mega-FTAs, we use the same method, data, and trade liberalization scenario as Akahori and Yamamoto [18] to measure the potential impact on GHG emissions of trade liberalization under the TPP. First, the GTAP model is used to estimate the changes in the economic variables of interest, such as the levels of sectoral fuel consumption, caused by the TPP. Second, the GTAP results, the GTAP $\mathrm{CO}_{2}$ emissions database, and the GTAP non- $\mathrm{CO}_{2}$ emissions database are used to estimate the potential impact of GHG emissions caused by the TPP.

To estimate the economic impact of the TPP, we use the static version of the GTAP model with standard closure and the GTAP 8.1 database for 2007. If the model used is the dynamic version of the GTAP model and a single period involves more than two years, the results should be converted to average annual values (Tassone et al. [20]). As the model used in this study is not dynamic and does not contain an explicit time dimension, we cannot attach a time dimension to the changes. The changes are interpreted as the differences between two equilibria; the original equilibrium in 2007 and the alternative equilibrium associated with the policy change. Antweiler et al. [21] decomposed the impact of trade on pollution into a scale effect, a composition effect, and a technique effect. The scale effect captures the impact of the change in the size of each economy. If the TPP increases the real GDP in each economy, the scale effect may increase GHG emissions. The composition effect captures the impact of the change in the industrial structure of each economy. As the TPP may have both positive and negative effects on the output of each industrial sector, the composition effect may have positive or negative effects on GHG emissions. The technique effect captures the impact of introducing cleaner production methods (e.g., biofuel production and utilization as a substitute for gasoline; Le et al. [22]). Although the technique effect is likely to decrease GHG emissions, it is difficult to properly assume such technical progress. As we do not assume any technical change that has a GHG reduction effect, our results capture the scale and composition effects of the TPP and cannot capture the technique effect.

Our trade liberalization scenario assumes the complete removal of all import tariffs among the TPP members. While it is unlikely that all TPP members would simultaneously remove all import tariffs across all sectors, our scenario provides an upper bound on the possible economic impact of the TPP.

Table 2 shows the regions and sectors we use in our analysis. In order to compare our results with the results for other mega-FTAs such as the Regional Comprehensive Economic Partnership (RCEP), we combine the 129 countries and regions in GTAP 8.1 into 26 regions. We retain the original 57 industries in the database.

We measure the environmental impact of the TPP by focusing only on GHG emissions as the form of environmental load because of data-availability limitations. We use the GTAP $\mathrm{CO}_{2}$ emissions database and the GTAP non- $\mathrm{CO}_{2}$ emissions database to measure the impact of the TPP on GHG emissions.

The GTAP $\mathrm{CO}_{2}$ emissions database provides detailed emissions data from the combustion of fossil fuels only, with $\mathrm{CO}_{2}$ emissions calculated by multiplying the amount of fuel consumed by the emission coefficients [4]. We assume that these emission coefficients remain unchanged following trade liberalization, and that the levels of $\mathrm{CO}_{2}$ emissions will, therefore, change by the same proportion as the levels of sectoral fuel consumption. Thus, we calculate the post-TPP levels of $\mathrm{CO}_{2}$ emissions by multiplying the initial level of $\mathrm{CO}_{2}$ emissions for each sector by the corresponding change in sectoral fuel consumption from the GTAP model results. For example, $\mathrm{CO}_{2}$ emissions produced by coal use in 
the electricity sector are calculated by multiplying the initial levels of $\mathrm{CO}_{2}$ emissions resulting from coal use in the electricity sector by the change in coal use in the electricity sector derived from the GTAP results.

Table 2. Regions and sectors.

\begin{tabular}{cccccc}
\hline & Region & & Sector & & Sector \\
\hline 1 & Japan & 1 & Paddy rice & 30 & Wood products \\
2 & Korea & 2 & Wheat & 31 & Paper products, publishing \\
3 & China & 3 & Cereal grains nec & 32 & Petroleum, coal products \\
4 & Indonesia & 4 & Vegetables, fruit, nuts & 33 & Chemical, rubber, plastic prods \\
5 & Malaysia & 5 & Oil seeds & 34 & Mineral products nec \\
6 & Philippines & 6 & Sugar cane, sugar beet & 35 & Ferrous metals \\
7 & Singapore & 7 & Plant-based fibers & 36 & Metals nec \\
8 & Thailand & 8 & Crops nec & 37 & Metal products \\
9 & Vietnam & 9 & Cattle, sheep, goats, horses & 38 & Motor vehicles and parts \\
10 & Cambodia & 10 & Animal products nec & 39 & Transport equipment nec \\
11 & Laos & 11 & Raw milk & 40 & Electronic equipment \\
12 & Other ASEAN & 12 & Wool, silkworm cocoons & 41 & Machinery and equipment nec \\
13 & India & 13 & Forestry & 42 & Manufactures nec \\
14 & Australia & 14 & Fishing & 43 & Electricity \\
15 & New Zealand & 15 & Coal & 44 & Gas manufacture, distribution \\
16 & United States & 16 & Oil & Water \\
17 & Canada & 17 & Gas & Construction \\
18 & Mexico & 18 & Minerals nec & 47 & Trade \\
19 & Peru & 19 & Meat: cattle, sheep, goats, horse & 48 & Transport nec \\
20 & Chile & 20 & Meat products nec & 49 & Sea transport \\
21 & Hong Kong & 21 & Vegetable oils and fats & 50 & Air transport \\
22 & Taiwan & 22 & Dairy products & 51 & Communication \\
23 & Russia & 23 & Processed rice & 52 & Financial services nec \\
24 & EU27 & 24 & Sugar & 53 & Insurance \\
25 & ROW1 & 25 & Food products nec & 54 & Business services nec \\
26 & ROW2 & 26 & Beverages and tobacco products & 55 & Recreation and other services \\
& & Textiles & 56 & PubAdmin/Defence/Health/Educat \\
& & Wearing apparel & 57 & Dwellings \\
\hline
\end{tabular}

Notes: Other ASEAN includes Brunei, Myanmar, and Timor-Leste. ROW1 includes the rest of Asian economies. ROW2 includes the rest of the world.

The GTAP non- $\mathrm{CO}_{2}$ emissions database enables us to measure methane $\left(\mathrm{CH}_{4}\right)$, nitrous oxide $\left(\mathrm{N}_{2} \mathrm{O}\right)$, and fluorinated GHGs (or F-gases) (namely, tetrafluorocarbon, hydrofluorocarbons, and sulfur hexafluoride) [5]. In this database, the levels of each type of non- $\mathrm{CO}_{2}$ emission are associated with output, endowment use, and input use by industry and private households [23]. We assume that the levels of non- $\mathrm{CO}_{2}$ gases change by the same proportion as the corresponding GTAP variables. This assumption allows us to calculate the post-TPP level of non- $\mathrm{CO}_{2}$ gases by multiplying the initial level of non- $\mathrm{CO}_{2}$ emissions by the corresponding sectoral changes derived from the GTAP results. For example, the paddy rice sector emits $\mathrm{CH}_{4}$. We then calculate the post-TPP level of $\mathrm{CH}_{4}$ emissions from land use in the paddy rice sector by multiplying the initial $\mathrm{CH}_{4}$ emissions by the change in land use for paddy rice derived from the GTAP results.

Data on anthropogenic fossil fuel combustion $\mathrm{CO}_{2}$ and all non- $\mathrm{CO}_{2}$ GHG emissions are provided in Table 3. All emission figures are converted to millions of metric tons $(\mathrm{Mt})$ of $\mathrm{CO}_{2}$ equivalent. Globally, about $70 \%$ of all GHG emissions are from $\mathrm{CO}_{2}$ emissions and about $30 \%$ are from non- $\mathrm{CO}_{2}$ emissions. Of the TPP members, the US is the largest GHG emitter, and Japan is the second largest GHG emitter. 
Table 3. GHG emissions by region ( $\mathrm{Mt} \mathrm{CO}_{2}$ equivalent) in 2007.

\begin{tabular}{|c|c|c|c|c|c|c|}
\hline \multirow{2}{*}{ Region } & \multicolumn{3}{|c|}{ Non- $\mathrm{CO}_{2}$ GHGs } & \multirow{2}{*}{$\begin{array}{c}\text { All } \\
\text { Non-CO }\end{array}$} & \multirow{2}{*}{$\mathrm{CO}_{2}$} & \multirow{2}{*}{$\begin{array}{c}\text { All } \\
\text { GHGs }\end{array}$} \\
\hline & $\mathrm{CH}_{4}$ & $\mathrm{~N}_{2} \mathrm{O}$ & F-Gas & & & \\
\hline TPP members & 1204 & 640 & 248 & 2092 & 8498 & 10,590 \\
\hline Japan & 18 & 31 & 40 & 89 & 1071 & 1161 \\
\hline Malaysia & 59 & 5 & 1 & 65 & 183 & 249 \\
\hline Singapore & 11 & 10 & 0 & 21 & 64 & 85 \\
\hline Vietnam & 69 & 12 & 0 & 81 & 92 & 173 \\
\hline Other ASEAN & 76 & 21 & 0 & 97 & 21 & 118 \\
\hline Australia & 112 & 25 & 6 & 143 & 381 & 524 \\
\hline New Zealand & 27 & 12 & 1 & 40 & 35 & 75 \\
\hline United States & 537 & 420 & 172 & 1129 & 5583 & 6712 \\
\hline Canada & 96 & 54 & 13 & 163 & 557 & 721 \\
\hline Mexico & 169 & 18 & 14 & 202 & 406 & 608 \\
\hline Peru & 18 & 23 & 0 & 42 & 30 & 72 \\
\hline Chile & 11 & 8 & 0 & 20 & 73 & 93 \\
\hline Korea & 35 & 9 & 12 & 55 & 423 & 478 \\
\hline China & 868 & 839 & 150 & 1857 & 5269 & 7126 \\
\hline Indonesia & 213 & 43 & 0 & 257 & 360 & 617 \\
\hline Philippines & 41 & 12 & 1 & 54 & 72 & 126 \\
\hline Thailand & 90 & 26 & 1 & 117 & 226 & 343 \\
\hline Cambodia & 23 & 18 & 0 & 41 & 5 & 46 \\
\hline Laos & 10 & 7 & 0 & 18 & 1 & 19 \\
\hline India & 504 & 80 & 13 & 596 & 1304 & 1900 \\
\hline Hong Kong & 1 & 0 & 0 & 1 & 80 & 81 \\
\hline Taiwan & 13 & 9 & 8 & 30 & 258 & 288 \\
\hline Russia & 333 & 55 & 23 & 411 & 1424 & 1834 \\
\hline EU27 & 434 & 375 & 64 & 873 & 4033 & 4906 \\
\hline ROW1 & 244 & 92 & 1 & 337 & 275 & 612 \\
\hline ROW2 & 2360 & 1045 & 62 & 3467 & 4296 & 7763 \\
\hline World & 6373 & 3248 & 584 & 10,205 & 26,524 & 36,729 \\
\hline
\end{tabular}

Notes: GTAP 8.1 $\mathrm{CO}_{2}$ emissions database and non- $\mathrm{CO}_{2}$ emissions database. Other ASEAN includes Brunei, Myanmar, and Timor-Leste. ROW1 includes the rest of Asian economies. ROW2 includes the rest of the world.

To measure the environmental efficiency of the macroeconomy, we introduce the emission intensity index (see [14]). The emission intensity indices of GHGs are calculated in terms of GHG emissions per unit of GDP output. A decrease in an emission intensity index means that environmental efficiency has improved.

\section{Results}

Under the assumption of the complete removal of all import tariffs among the TPP members, all members are likely to experience an increase in total exports and imports. In terms of real GDP, the US and Peru are likely to experience a slight decrease. Across the countries in the TPP, on average, real GDP, total exports and imports increase by $0.06 \%, 1.33 \%$, and $1.56 \%$, respectively (Table 4 ). Non-TPP economies are likely to experience a decrease in real GDP. In percentage terms, the increases are the highest in Vietnam: $1.39 \%$ in GDP, $10.55 \%$ in total exports, and $15.22 \%$ in total imports.

When comparing our results with the previous studies' results, we found the following in common. Areerat et al. [12] also showed that the real GDP of the US and Peru decrease slightly. Burfisher et al. [6], Kawasaki [8], Lee and Itakura [10], Petri et al. [11], and Areerat et al. [12] also showed that Vietnam has the highest real GDP growth rate. Petri et al. [11] also showed that the TPP increases total exports in all TPP members. 
Table 4. Economic impact of the TPP (\%).

\begin{tabular}{cccc}
\hline Region & Real GDP & Total Export & Total Import \\
\hline TPP members & 0.06 & 1.33 & 1.56 \\
Japan & 0.20 & 1.78 & 3.10 \\
Malaysia & 0.38 & 1.30 & 3.18 \\
Singapore & 0.01 & 0.57 & 0.79 \\
Vietnam & 1.39 & 10.55 & 15.22 \\
Other ASEAN & 0.07 & 1.23 & 2.60 \\
Australia & 0.00 & 0.76 & 1.96 \\
New Zealand & 0.06 & 0.13 & 2.70 \\
United States & -0.00 & 0.80 & 0.53 \\
Canada & 0.18 & 2.36 & 2.02 \\
Mexico & 0.04 & 0.68 & 1.05 \\
Peru & -0.00 & 2.78 & 5.52 \\
Chile & 0.02 & 0.12 & 0.38 \\
Korea & -0.02 & 0.07 & -0.19 \\
China & -0.03 & -0.12 & -0.31 \\
Indonesia & -0.01 & -0.09 & -0.45 \\
Philippines & -0.02 & 0.14 & -0.06 \\
Thailand & -0.06 & 0.01 & -0.51 \\
Cambodia & -0.09 & 0.46 & -1.15 \\
Laos & -0.00 & 0.14 & 0.12 \\
India & -0.01 & 0.07 & -0.19 \\
Hong Kong & -0.00 & 0.05 & -0.09 \\
Taiwan & -0.01 & -0.10 & -0.27 \\
Russia & 0.01 & 0.02 & 0.01 \\
EU27 & -0.00 & 0.08 & -0.07 \\
ROW1 & -0.01 & -0.01 & -0.45 \\
ROW2 & -0.00 & -0.00 & -0.12 \\
\hline
\end{tabular}

Notes: Other ASEAN includes Brunei, Myanmar, and Timor-Leste. ROW1 includes the rest of Asian economies. ROW2 includes the rest of the world.

In this study, we focus only on the impact of tariff elimination. Thus, our results for real GDP are relatively small when compared with the results of other studies that include the reduction of NTMs (non-tariff measures) such as Kawasaki [8] and Petri et al. [11]. While the maximum percentage change in GDP for our study is $1.39 \%$, the maximum percentage change in GDP by the simulations that incorporate NTMs ranges from 2.66\% (Lee and Itakura [10]) to 20.6\% (Kawasaki [8]).

In Tables 5-7, we focus on Japan and the US as the two largest TPP members (in terms of real GDP), Australia and New Zealand, given that they have the highest and second highest growth rates in non- $\mathrm{CO}_{2}$ emissions, and China, India, and the European Union (EU) as key non-TPP member economies throughout the following discussion.

Table 5 shows the changes in the sectoral output for a year in percentage terms. Among the TPP participants, farm output (defined as the agricultural sectors "paddy rice" to "wool, silkworm cocoons," which correspond to sectors 1-12 in Table 2) declines in Japan, but increases in Australia, New Zealand, and the US. In percentage terms, the declines in output from the wheat sector $(-77.55 \%)$ and the paddy rice sector $(-37.30 \%)$ are the two largest sectoral output changes in Japan. In contrast, the rate of growth in paddy rice production is the highest or second highest of all sectors in Australia $(193.46 \%)$, New Zealand (17.49\%), and the US (56.41\%). Livestock sector output decreases in Japan, but increases in Australia, New Zealand, and the US. Output in the electricity sector, one of the largest sources of $\mathrm{CO}_{2}$ emissions, increases in Japan, but decreases in Australia, New Zealand, and the US. 
Table 5. Impact on sectoral outputs (\%).

\begin{tabular}{|c|c|c|c|c|c|c|c|}
\hline Sector & Japan & Australia & New Zealand & United States & China & India & EU \\
\hline Paddy rice & -37.30 & 193.46 & 17.49 & 56.41 & -0.21 & 0.09 & 0.02 \\
\hline Wheat & -77.55 & -0.95 & -0.02 & 2.19 & -0.08 & -0.11 & 0.24 \\
\hline Cereal grains nec & -8.64 & 7.50 & 1.47 & 0.40 & -0.43 & 0.01 & -0.10 \\
\hline Vegetables, fruit, nuts & 0.01 & -0.76 & -1.69 & -0.01 & -0.15 & 0.02 & 0.12 \\
\hline Oil seeds & 5.42 & -2.10 & -6.40 & -0.80 & 0.40 & 0.07 & 0.15 \\
\hline Sugar cane, sugar beet & -3.59 & 3.22 & 0.24 & -1.70 & -0.16 & -0.03 & -0.04 \\
\hline Plant-based fibers & 23.34 & -3.07 & -2.37 & -1.15 & 0.04 & 0.07 & 0.26 \\
\hline Crops nec & -6.30 & -2.40 & -6.23 & 2.36 & -0.83 & -0.22 & 0.02 \\
\hline Cattle,sheep,goats,horses & -18.51 & 9.24 & -2.55 & 0.46 & -0.18 & -0.01 & 0.03 \\
\hline Animal products nec & -6.15 & -2.37 & -3.99 & 2.66 & -0.45 & -0.04 & -0.48 \\
\hline Raw milk & -23.86 & 1.00 & 12.66 & 0.85 & 0.25 & -0.02 & -0.18 \\
\hline Wool, silkworm cocoons & 0.82 & -3.93 & -6.48 & 0.22 & 1.94 & 0.42 & 5.65 \\
\hline Forestry & -0.35 & -0.22 & -1.18 & -0.01 & 0.24 & 0.14 & 0.08 \\
\hline Fishing & 0.62 & 0.42 & 1.53 & 0.27 & -0.13 & -0.03 & -0.01 \\
\hline Coal & -0.18 & -0.12 & -0.70 & -0.00 & 0.08 & 0.09 & 0.05 \\
\hline Oil & -0.27 & -0.06 & -0.60 & 0.02 & 0.08 & 0.11 & 0.09 \\
\hline Gas & -0.41 & -0.23 & -0.81 & -0.04 & 0.03 & 0.07 & 0.03 \\
\hline Minerals nec & 0.25 & -0.51 & -0.58 & -0.01 & 0.14 & 0.18 & 0.01 \\
\hline Meat: cattle,sheep,goats,horse & -22.73 & 11.07 & -3.36 & 0.53 & -0.24 & -0.48 & 0.32 \\
\hline Meat products nec & -11.00 & -1.88 & -4.34 & 4.60 & -1.83 & -0.51 & -0.70 \\
\hline Vegetable oils and fats & 1.07 & -2.30 & -0.40 & 0.47 & 0.14 & 0.07 & 0.03 \\
\hline Dairy products & -31.39 & 0.96 & 15.05 & 0.88 & 0.25 & -0.06 & -0.20 \\
\hline Processed rice & -23.45 & 36.58 & -0.61 & 63.81 & -0.47 & -0.01 & -0.05 \\
\hline Sugar & -3.53 & 12.17 & 0.26 & -1.94 & -0.16 & -0.03 & -0.07 \\
\hline Food products nec & 1.70 & 1.31 & 3.00 & 0.71 & -0.44 & -0.19 & -0.12 \\
\hline Beverages and tobacco products & 0.80 & 0.53 & -0.12 & 0.09 & -0.02 & -0.03 & -0.03 \\
\hline Textiles & 20.76 & -0.29 & -3.91 & -0.96 & -0.19 & -0.33 & -0.18 \\
\hline Wearing apparel & 1.19 & 0.42 & -2.13 & -1.93 & -0.94 & -1.52 & -0.30 \\
\hline Leather products & 5.06 & -0.70 & -4.79 & 0.39 & -0.90 & 0.12 & -0.28 \\
\hline Wood products & -0.58 & -0.28 & -0.86 & -0.03 & 0.20 & 0.13 & 0.12 \\
\hline Paper products, publishing & -0.08 & -0.06 & -1.66 & 0.04 & 0.12 & 0.02 & 0.02 \\
\hline Petroleum, coal products & 0.36 & -0.29 & -0.02 & -0.00 & -0.06 & -0.02 & 0.03 \\
\hline Chemical,rubber,plastic prods & 0.52 & -1.05 & -1.19 & -0.04 & 0.17 & 0.00 & 0.04 \\
\hline Mineral products nec & 0.47 & 0.30 & -0.19 & -0.07 & 0.02 & -0.06 & -0.05 \\
\hline Ferrous metals & 1.71 & -1.01 & -5.33 & -0.36 & -0.01 & -0.03 & -0.07 \\
\hline Metals nec & 0.53 & -1.60 & -7.07 & -0.19 & 0.38 & 0.36 & 0.24 \\
\hline Metal products & 0.54 & -0.24 & -2.78 & -0.18 & 0.08 & -0.02 & -0.02 \\
\hline Motor vehicles and parts & 3.59 & -7.59 & -6.77 & -0.58 & -0.19 & -0.05 & -0.17 \\
\hline Transport equipment nec & 0.08 & -0.63 & -1.32 & -0.17 & 0.13 & 0.19 & 0.13 \\
\hline Electronic equipment & -1.09 & -1.00 & -2.95 & 0.11 & 0.69 & 0.35 & 0.50 \\
\hline Machinery and equipment nec & -0.70 & -0.97 & -5.47 & -0.19 & 0.27 & 0.11 & 0.13 \\
\hline Manufactures nec & 0.46 & -0.10 & -1.26 & -0.00 & 0.20 & 0.12 & -0.00 \\
\hline Electricity & 0.20 & -0.34 & -0.85 & -0.01 & 0.05 & -0.00 & 0.00 \\
\hline Gas manufacture, distribution & -0.32 & -0.56 & -0.86 & -0.01 & 0.06 & 0.02 & 0.10 \\
\hline Water & 0.03 & -0.04 & 0.26 & 0.00 & 0.03 & 0.01 & -0.00 \\
\hline Construction & 0.35 & 0.71 & 1.07 & -0.01 & -0.09 & -0.10 & -0.14 \\
\hline Trade & 0.19 & -0.08 & -0.05 & -0.00 & 0.05 & -0.03 & 0.01 \\
\hline Transport nec & -0.11 & 0.06 & -1.11 & 0.01 & 0.03 & -0.02 & 0.05 \\
\hline Sea transport & -0.04 & -0.17 & -1.13 & 0.24 & 0.31 & 0.57 & 0.52 \\
\hline Air transport & -0.62 & -0.58 & -1.07 & 0.00 & 0.25 & 0.13 & 0.12 \\
\hline Communication & 0.08 & -0.12 & -0.38 & -0.01 & 0.02 & 0.09 & 0.04 \\
\hline Financial services nec & 0.05 & -0.09 & 0.14 & -0.01 & 0.05 & 0.02 & 0.06 \\
\hline Insurance & -0.18 & -0.19 & -0.44 & -0.02 & 0.07 & 0.07 & 0.05 \\
\hline Business services nec & 0.06 & -0.14 & -0.33 & -0.00 & 0.03 & 0.24 & 0.01 \\
\hline Recreation and other services & 0.06 & -0.23 & -0.52 & -0.01 & 0.00 & 0.13 & 0.02 \\
\hline PubAdmin/Defence/Health/Educat & 0.08 & -0.13 & 0.16 & -0.01 & -0.06 & -0.02 & -0.00 \\
\hline Dwellings & 0.07 & -0.09 & 0.34 & -0.02 & -0.06 & -0.04 & -0.01 \\
\hline
\end{tabular}

Lee and Itakura [10] showed that farm sector outputs decrease in Japan and increase in the US. Burfisher et al. [6] also showed that farm sector outputs decrease in Japan and increase in Australia, New Zealand, and the US. Compared with the results of RCEP [18] and FTAAP [19], the impact of the TPP on the paddy rice sector output is smaller than that of the RCEP and the FTAAP.

Table 6 shows the impact of the TPP on GHG emissions. The figures in the table are changes in the GHG emissions for a year in $\mathrm{Mt}$ of $\mathrm{CO}_{2}$ equivalent. In the following tables, the figures in parentheses are percentage deviations from the initial period, calculated as the amount of change 
divided by the initial amount. The TPP increases total TPP member and global GHG emissions by $17.79 \mathrm{Mt} \mathrm{CO} 2$ eq. $(0.17 \%)$ and $22.79 \mathrm{Mt} \mathrm{CO}_{2}$ eq. $(0.06 \%)$, respectively. As for our main research question, these results indicate that the TPP is likely to increase both TPP member and global GHG emissions. The main reason for increasing TPP member and global GHG emissions is non- $\mathrm{CO}_{2}$ emissions growth in Australia (7.05 $\mathrm{Mt} \mathrm{CO}_{2}$ eq.) and the US ( $8.38 \mathrm{Mt} \mathrm{CO}_{2}$ eq.). However, the magnitude of the change is relatively small (only a $0.17 \%$ increase) when compared with the original level of emissions in Table 3 . Note that because of the assumptions in our analysis these changes in the GHG emissions reflect only the composition and scale effects. If some technical change that has a GHG reducing effect is assumed and the technique effect is incorporated, GHG emissions might decline.

Table 6. Environmental impact of TPP $\left(\mathrm{Mt} \mathrm{CO}_{2}\right.$ equivalent, \%).

\begin{tabular}{ccccccc}
\hline Region & \multicolumn{2}{c}{$\mathrm{CO}_{2}$} & \multicolumn{2}{c}{ Non-CO } & \multicolumn{2}{c}{ GHG } \\
\hline TPP members & $\mathbf{2 . 9 9}$ & $\mathbf{( 0 . 0 4 )}$ & $\mathbf{1 4 . 8 0}$ & $\mathbf{( 0 . 7 1 )}$ & $\mathbf{1 7 . 7 9}$ & $\mathbf{( 0 . 1 7 )}$ \\
Japan & 2.38 & $(0.22)$ & -5.97 & $(-6.70)$ & -3.59 & $(-0.31)$ \\
Malaysia & 0.14 & $(0.07)$ & 0.30 & $(0.45)$ & 0.43 & $(0.17)$ \\
Singapore & 0.41 & $(0.64)$ & 0.09 & $(0.45)$ & 0.51 & $(0.60)$ \\
Vietnam & 1.04 & $(1.13)$ & 0.64 & $(0.79)$ & 1.68 & $(0.97)$ \\
Other ASEAN & -0.05 & $(-0.26)$ & 0.65 & $(0.67)$ & 0.60 & $(0.51)$ \\
Australia & -0.98 & $(-0.26)$ & 7.05 & $(4.93)$ & 6.08 & $(1.16)$ \\
New Zealand & -0.18 & $(-0.51)$ & 1.55 & $(3.91)$ & 1.37 & $(1.83)$ \\
United States & 0.64 & $(0.01)$ & 8.38 & $(0.74)$ & 9.03 & $(0.13)$ \\
Canada & 0.19 & $(0.03)$ & -0.13 & $(-0.08)$ & 0.06 & $(0.01)$ \\
Mexico & -0.45 & $(-0.11)$ & 2.09 & $(1.04)$ & 1.64 & $(0.27)$ \\
Peru & -0.17 & $(-0.56)$ & 0.02 & $(0.04)$ & -0.15 & $(-0.21)$ \\
Chile & 0.02 & $(0.02)$ & 0.12 & $(0.62)$ & 0.14 & $(0.15)$ \\
Korea & -0.04 & $(-0.01)$ & 0.10 & $(0.18)$ & 0.06 & $(0.01)$ \\
China & 2.76 & $(0.05)$ & -1.75 & $(-0.09)$ & 1.01 & $(0.01)$ \\
Indonesia & -0.06 & $(-0.02)$ & 1.13 & $(0.44)$ & 1.07 & $(0.17)$ \\
Philippines & -0.03 & $(-0.04)$ & 0.19 & $(0.35)$ & 0.16 & $(0.12)$ \\
Thailand & 0.19 & $(0.09)$ & -0.07 & $(-0.06)$ & 0.12 & $(0.03)$ \\
Cambodia & -0.00 & $(-0.05)$ & 0.01 & $(0.03)$ & 0.01 & $(0.02)$ \\
Laos & 0.00 & $(0.11)$ & -0.01 & $(-0.03)$ & -0.00 & $(-0.02)$ \\
India & 0.37 & $(0.03)$ & -0.04 & $(-0.01)$ & 0.34 & $(0.02)$ \\
Hong Kong & 0.07 & $(0.08)$ & 0.00 & $(0.06)$ & 0.07 & $(0.08)$ \\
Taiwan & -0.40 & $(-0.16)$ & 0.03 & $(0.11)$ & -0.37 & $(-0.13)$ \\
Russia & -0.29 & $(-0.02)$ & 0.07 & $(0.02)$ & -0.22 & $(-0.01)$ \\
EU27 & 0.71 & $(0.02)$ & -0.05 & $(-0.01)$ & 0.66 & $(0.01)$ \\
ROW1 & 0.24 & $(0.09)$ & 0.18 & $(0.05)$ & 0.42 & $(0.07)$ \\
ROW2 & 0.10 & $(0.00)$ & 1.58 & $(0.05)$ & 1.68 & $(0.02)$ \\
World & $\mathbf{6 . 6 2}$ & $\mathbf{( 0 . 0 2 )}$ & $\mathbf{1 6 . 1 7}$ & $\mathbf{( 0 . 1 6 )}$ & $\mathbf{2 2 . 7 9}$ & $\mathbf{( 0 . 0 6 )}$ \\
\hline
\end{tabular}

Notes: Figures in parentheses are percentage deviations from the initial period. Other ASEAN includes Brunei, Myanmar, and Timor-Leste. ROW1 includes the rest of Asian economies. ROW2 includes the rest of the world.

Total TPP member and global $\mathrm{CO}_{2}$ emissions increase by $2.99 \mathrm{Mt} \mathrm{CO}_{2}$ eq. $(0.04 \%)$ and $6.62 \mathrm{Mt}^{\mathrm{CO}_{2}}$ eq. $(0.02 \%)$, respectively. Total TPP member and global non- $\mathrm{CO}_{2}$ emissions increase by $14.80 \mathrm{Mt} \mathrm{CO}_{2}$ eq. $(0.71 \%)$ and $16.17 \mathrm{MtCO}_{2}$ eq. $(0.16 \%)$, respectively. Among the non-TPP members, the total GHG emissions of China, India, and the EU increase by $1.01 \mathrm{Mt} \mathrm{CO}_{2}$ eq. $(0.01 \%), 0.34 \mathrm{Mt} \mathrm{CO}_{2}$ eq. $(0.02 \%)$, and $0.66 \mathrm{Mt} \mathrm{CO}_{2}$ eq. $(0.01 \%)$, respectively.

Focusing on individual economy results, Japan experiences the largest increase in $\mathrm{CO}_{2}$ emissions (2.38 Mt $\mathrm{CO}_{2}$ eq.) among TPP members. In terms of non- $\mathrm{CO}_{2}$ emissions, Japan experiences the largest decrease ( $-5.97 \mathrm{MtCO}_{2}$ eq.), and the US and Australia experience the largest and the second largest increases ( $8.38 \mathrm{Mt} \mathrm{CO}_{2}$ eq. and $7.05 \mathrm{Mt} \mathrm{CO}$ eq.) among the TPP members. Among non-TPP members, China also experiences the largest change in $\mathrm{CO}_{2}\left(2.76 \mathrm{Mt} \mathrm{CO}_{2}\right.$ eq.) and non- $\mathrm{CO}_{2}$ emissions $\left(-1.75 \mathrm{Mt} \mathrm{CO}_{2}\right.$ eq.). In percentage terms, Australia has the largest increase in non- $\mathrm{CO}_{2}$ emissions $(4.93 \%)$ and New Zealand has the second largest increase in non- $\mathrm{CO}_{2}$ emissions (3.91\%), while Japan has the largest decrease in non- $\mathrm{CO}_{2}$ emissions $(-6.70 \%)$. 
In Figure 1, we compare the environmental impact of the TPP and that of other mega-FTAs, including TPP, FTAAP, RCEP, JCKFTA, the Japan-EU FTA (JEUFTA), and the Transatlantic Trade and Investment Partnership (TTIP). We estimate the results for other mega-FTAs using the same model as used in this study. The trade liberalization scenarios for the mega-FTAs are the complete removal of all import tariffs among each FTA member. Among the four Asia-Pacific mega-FTAs (TPP, FTAAP [19], RCEP [18], and JCKFTA), only RCEP shows a decrease in GHG emissions. This is mainly because of the large decrease in $\mathrm{CO}_{2}$ emissions from the Indian electricity sector. As of the end of January 2017, India had joined the RCEP, but not the TPP. Thus, whether India chooses to participate in the Asia-Pacific mega-FTA will have a significant impact on GHG emissions in the Asia-Pacific region and the world. Among the three FTAs that increase GHG emissions (TPP, FTAAP, and JCKFTA), the TPP shows the smallest increase in FTA members' GHG emissions and the second smallest increase in global GHG emissions.

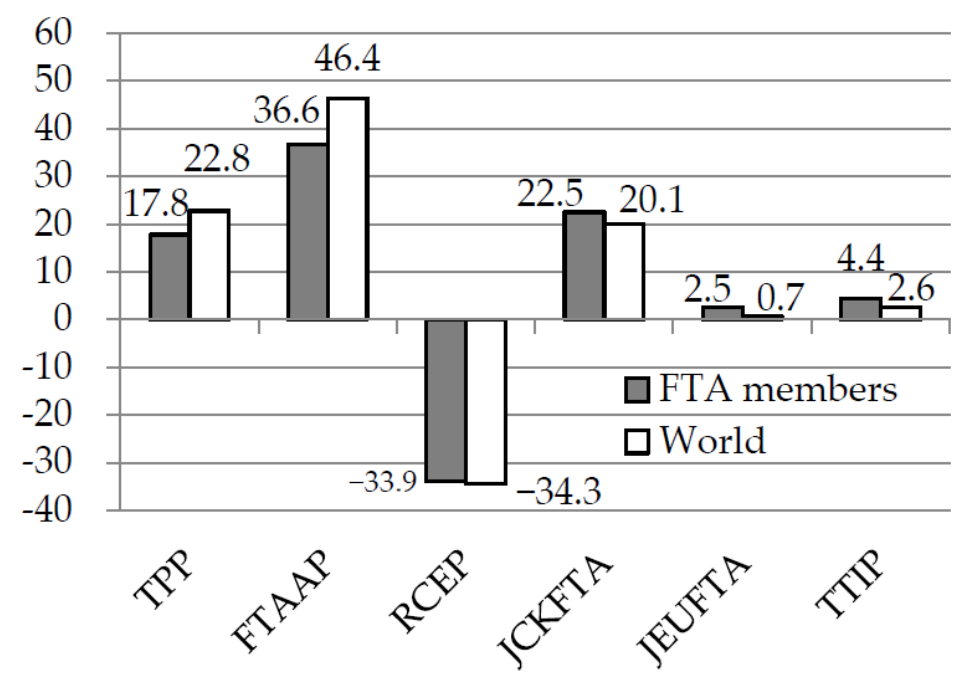

Figure 1. Environmental impact of mega-FTAs on GHG emissions ( $\mathrm{Mt} \mathrm{CO}_{2}$ equivalent). Source: Authors' estimation.

Table 7 shows the five sectors that contribute most to the absolute changes in $\mathrm{CO}_{2}, \mathrm{CH}_{4}$, and $\mathrm{N}_{2} \mathrm{O}$ emissions. We omitted F-gases from the table because relatively few sectors emit these GHGs. In terms of $\mathrm{CO}_{2}$ emissions, the electricity sector is shown for all economies except the EU.

Regarding the $\mathrm{CH}_{4}$ emissions of the top five sectors, the paddy rice sector experiences the largest decrease in Japan ( $-1.36 \mathrm{Mt} \mathrm{CO}_{2}$ eq.). Australia and the US also include the paddy rice sector in their top five sectors. In percentage terms, $\mathrm{CH}_{4}$ emissions from the raw milk sector decrease the most in Japan $(-25.93 \%)$. These results arise mainly because of the large decrease in output from the paddy rice sector and livestock sectors in Japan and the large increase in output from the rice sector and livestock sectors in Australia, New Zealand, and the US, as shown in Table 5. While all economies in Table 7 have a cattle, sheep, goats, and horses sector, all economies in Table 7 other than China, have a raw milk sector.

Regarding the $\mathrm{N}_{2} \mathrm{O}$ emissions of the top five sectors, in percentage terms, the paddy rice sector shows the largest change in Japan $(-37.30 \%)$, Australia $(193.46 \%)$, and the US $(56.41 \%)$. These results are also a result of the large decrease in output from the paddy rice sector in Japan and the large increase in output from the paddy rice sector in Australia and the US, as shown in Table 5. All economies in Table 7 other than the EU include the cattle, sheep, goats, and horses sector in their top five $\mathrm{N}_{2} \mathrm{O}$-emitting sectors.

Regarding $\mathrm{CH}_{4}$ emissions, three or more of the top five emitting sectors in each economy are farming-related sectors. Regarding $\mathrm{N}_{2} \mathrm{O}$ emissions, all of the top five emitting sectors in each economy are farming-related sectors. 
Table 7. Most affected sectors by country for GHG emissions ( $\mathrm{Mt} \mathrm{CO}_{2}$ equivalent, \%).

\begin{tabular}{|c|c|c|c|c|c|c|c|c|}
\hline Japan & $\mathrm{CO}_{2}$ & & & $\mathrm{CH}_{4}$ & & & $\mathrm{~N}_{2} \mathrm{O}$ & \\
\hline Electricity & 0.90 & $(0.20)$ & Paddy rice & -1.36 & $(-23.38)$ & Paddy rice & -0.91 & $(-37.30)$ \\
\hline Ferrous metals & 0.87 & $(1.72)$ & Raw milk & -0.83 & $(-25.93)$ & Animal products nec & -0.61 & $(-8.14)$ \\
\hline CRP & 0.29 & $(0.55)$ & $\begin{array}{l}\text { Cattle, sheep, goats, } \\
\text { horses }\end{array}$ & -0.70 & $(-20.60)$ & $\begin{array}{l}\text { Cattle, sheep, goats, } \\
\text { horses }\end{array}$ & -0.50 & $(-20.52)$ \\
\hline Dairy products & -0.25 & $(-31.39)$ & Animal products nec & -0.05 & $(-8.24)$ & Raw milk & -0.45 & $(-25.81)$ \\
\hline Paddy rice & -0.23 & $(-37.30)$ & PADHE & 0.00 & $(0.08)$ & Crops nec & -0.12 & $(-6.30)$ \\
\hline Australia & $\mathrm{CO}_{2}$ & & & $\mathrm{CH}_{4}$ & & & $\mathrm{~N}_{2} \mathrm{O}$ & \\
\hline Electricity & -0.71 & $(-0.34)$ & $\begin{array}{l}\text { Cattle, sheep, goats, } \\
\text { horses }\end{array}$ & 6.24 & $(9.76)$ & $\begin{array}{l}\text { Cattle, sheep, goats, } \\
\text { horses }\end{array}$ & 0.62 & $(8.67)$ \\
\hline Metals nec & -0.22 & $(-1.59)$ & Raw milk & 0.13 & $(1.87)$ & Cereal grains nec & 0.09 & $(7.50)$ \\
\hline Air transport & -0.11 & $(-0.57)$ & Paddy rice & 0.12 & $(142.98)$ & Paddy rice & 0.09 & (193.46) \\
\hline CRP & -0.05 & $(-1.06)$ & Coal & -0.03 & $(-0.12)$ & Raw milk & 0.03 & $(1.26)$ \\
\hline Minerals nec & -0.04 & $(-0.50)$ & Animal products nec & -0.02 & $(-1.69)$ & Crops nec & -0.03 & $(-2.40)$ \\
\hline New Zealand & $\mathrm{CO}_{2}$ & & & $\mathrm{CH}_{4}$ & & & $\mathrm{~N}_{2} \mathrm{O}$ & \\
\hline Air transport & -0.11 & $(-1.06)$ & Raw milk & 1.35 & $(14.07)$ & Raw milk & 0.65 & $(13.44)$ \\
\hline Electricity & -0.06 & $(-0.85)$ & $\begin{array}{l}\text { Cattle, sheep, goats, } \\
\text { horses }\end{array}$ & -0.27 & $(-1.81)$ & Cattle,sheep,goats,horses & -0.11 & $(-1.92)$ \\
\hline Transport nec & -0.05 & $(-1.10)$ & Animal products nec & -0.01 & $(-3.32)$ & Vegetables, fruit, nuts & -0.01 & $(-1.69)$ \\
\hline Dairy products & 0.04 & $(15.05)$ & Coal & -0.00 & $(-0.70)$ & Animal products nec & -0.01 & $(-3.84)$ \\
\hline Raw milk & 0.02 & $(12.66)$ & $\begin{array}{l}\text { Gas manufacture, } \\
\text { distribution }\end{array}$ & -0.00 & $(-0.86)$ & Crops nec & -0.00 & $(-6.23)$ \\
\hline United States & $\mathrm{CO}_{2}$ & & & $\mathrm{CH}_{4}$ & & & $\mathrm{~N}_{2} \mathrm{O}$ & \\
\hline Paddy rice & 0.52 & $(56.41)$ & Paddy rice & 2.85 & $(44.89)$ & Paddy rice & 1.61 & $(56.41)$ \\
\hline Electricity & -0.26 & $(-0.01)$ & $\begin{array}{l}\text { Cattle, sheep, goats, } \\
\text { horses }\end{array}$ & 0.82 & $(0.90)$ & Animal products nec & 0.71 & $(2.84)$ \\
\hline $\begin{array}{l}\text { Food products } \\
\text { nec }\end{array}$ & 0.21 & $(0.71)$ & Animal products nec & 0.75 & $(3.26)$ & Cereal grains nec & 0.47 & $(0.40)$ \\
\hline $\begin{array}{l}\text { Meat products } \\
\text { nec }\end{array}$ & 0.18 & $(4.60)$ & Raw milk & 0.55 & $(1.32)$ & Cattle,sheep,goats,horses & 0.39 & $(0.82)$ \\
\hline Processed rice & 0.15 & $(63.81)$ & PADHE & -0.01 & $(-0.01)$ & Wheat & 0.34 & $(2.19)$ \\
\hline China & $\mathrm{CO}_{2}$ & & & $\mathrm{CH}_{4}$ & & & $\mathrm{~N}_{2} \mathrm{O}$ & \\
\hline Electricity & 2.20 & $(0.07)$ & $\begin{array}{l}\text { Cattle, sheep, goats, } \\
\text { horses }\end{array}$ & -0.49 & $(-0.27)$ & Animal products nec & -0.63 & $(-0.55)$ \\
\hline CRP & 0.32 & $(0.18)$ & Coal & 0.18 & $(0.08)$ & Vegetables, fruit, nuts & -0.56 & $(-0.15)$ \\
\hline Sea transport & 0.30 & $(0.31)$ & Animal products nec & -0.15 & $(-0.56)$ & Cereal grains nec & -0.16 & $(-0.43)$ \\
\hline Metals nec & 0.16 & $(0.39)$ & PADHE & -0.10 & $(-0.06)$ & $\begin{array}{l}\text { Cattle, sheep, goats, } \\
\text { horses }\end{array}$ & -0.14 & $(-0.26)$ \\
\hline $\begin{array}{l}\text { Mineral } \\
\text { products nec }\end{array}$ & 0.15 & $(0.04)$ & Paddy rice & -0.04 & $(-0.02)$ & Paddy rice & -0.13 & $(-0.21)$ \\
\hline India & $\mathrm{CO}_{2}$ & & & $\mathrm{CH}_{4}$ & & & $\mathrm{~N}_{2} \mathrm{O}$ & \\
\hline Electricity & 0.45 & $(0.06)$ & Paddy rice & 0.09 & $(0.10)$ & Crops nec & -0.03 & $(-0.22)$ \\
\hline Transport nec & -0.02 & $(-0.02)$ & $\begin{array}{l}\text { Cattle, sheep, goats, } \\
\text { horses }\end{array}$ & -0.07 & $(-0.03)$ & Wheat & -0.01 & $(-0.11)$ \\
\hline Metals nec & 0.01 & $(0.40)$ & PADHE & -0.02 & $(-0.02)$ & Raw milk & -0.00 & $(-0.04)$ \\
\hline Textiles & -0.01 & $(-0.30)$ & Coal & 0.02 & $(0.09)$ & Oil seeds & 0.00 & $(0.07)$ \\
\hline Trade & 0.01 & $(0.03)$ & Raw milk & -0.01 & $(-0.04)$ & $\begin{array}{l}\text { Cattle, sheep, goats, } \\
\text { horses }\end{array}$ & -0.00 & $(-0.03)$ \\
\hline EU27 & $\mathrm{CO}_{2}$ & & & $\mathrm{CH}_{4}$ & & & $\mathrm{~N}_{2} \mathrm{O}$ & \\
\hline Sea transport & 0.75 & $(0.52)$ & Animal products nec & -0.21 & $(-0.50)$ & Animal products nec & -0.09 & $(-0.49)$ \\
\hline Transport nec & 0.38 & $(0.05)$ & Raw milk & -0.13 & $(-0.19)$ & Wheat & 0.07 & $(0.24)$ \\
\hline Air transport & 0.24 & $(0.12)$ & $\begin{array}{l}\text { Cattle, sheep, goats, } \\
\text { horses }\end{array}$ & 0.03 & $(0.03)$ & Raw milk & -0.04 & $(-0.19)$ \\
\hline $\begin{array}{l}\text { Mineral } \\
\text { products nec }\end{array}$ & -0.06 & $(-0.06)$ & $\begin{array}{l}\text { Gas manufacture, } \\
\text { distribution }\end{array}$ & 0.02 & $(0.10)$ & Cereal grains nec & -0.03 & $(-0.10)$ \\
\hline Ferrous metals & -0.05 & $(-0.07)$ & Coal & 0.02 & $(0.05)$ & Vegetables, fruit, nuts & 0.03 & $(0.12)$ \\
\hline
\end{tabular}

Notes: Figures in parentheses are percentage deviations from the initial period. CRP stands for Chemical, rubber, plastic products. PADHE stands for PubAdmin/Defence/Health/Educat.

To measure the environmental efficiency of the macroeconomy, the emission intensity indices of GHGs are calculated in terms of GHG emissions per unit of GDP output. The changes in the GHG emissions intensity indexes are shown in Table 8. The GHG emissions intensity index of all TPP members increases by $0.11 \%$, suggesting that the TPP could reduce the overall environmental efficiency of TPP 
members' macroeconomies in terms of GHG emissions. As shown in Table 7, this is attributable mainly to the significant increase in non- $\mathrm{CO}_{2}$ emissions from the agricultural sectors in Australia and the US.

Table 8. Changes in emission intensity indices (emissions per unit of GDP) of GHG emissions (\%).

\begin{tabular}{cccc}
\hline Region & $\mathbf{C O}_{\mathbf{2}}$ & Non-CO & GHG \\
\hline TPP members & $\mathbf{- 0 . 0 2}$ & $\mathbf{0 . 6 5}$ & $\mathbf{0 . 1 1}$ \\
Japan & 0.03 & -6.88 & -0.50 \\
Malaysia & -0.30 & 0.08 & -0.20 \\
Singapore & 0.63 & 0.44 & 0.58 \\
Vietnam & -0.25 & -0.59 & -0.41 \\
Other ASEAN & -0.32 & 0.60 & 0.44 \\
Australia & -0.26 & 4.92 & 1.16 \\
New Zealand & -0.58 & 3.85 & 1.77 \\
United States & 0.01 & 0.74 & 0.13 \\
Canada & -0.14 & -0.25 & -0.17 \\
Mexico & -0.16 & 0.99 & 0.23 \\
Peru & -0.56 & 0.05 & -0.21 \\
Chile & 0.01 & 0.60 & 0.13 \\
\hline Note: Other ASEAN includes Brunei, Myanmar, and Timor-Leste.
\end{tabular}

\section{Conclusions}

The purpose of this paper is to contribute to the debate over the TPP and GHG emissions by asking the following question: Does the TPP increase or decrease GHG emissions? In order to answer this question, we measured the potential impact on GHG emissions caused by the TPP using the GTAP model, the GTAP $\mathrm{CO}_{2}$ emissions database, and the GTAP non- $\mathrm{CO}_{2}$ emissions database. Our scenario assumed the complete removal of all import tariffs among the TPP members.

Our results showed that the TPP is likely to increase total TPP member and global GHG emissions. They also showed that non- $\mathrm{CO}_{2}$ emissions growth in Australia and the US is the main reason for rising TPP member and global GHG emissions. Compared with other Asia-Pacific mega-FTAs, the TPP showed the smallest increase in FTA members' GHG emissions and the second smallest increase in global GHG emissions. The magnitude of the change in GHG emissions under the TPP is also small (only a $0.17 \%$ increase) when compared with the original level of emissions. If some technical change that has a GHG reducing effect occurs concurrently with the enactment of the TPP, GHG emissions may decline.

Acknowledgments: This work was supported by JSPS KAKENHI Grant Numbers JP26252036 and JP16H06202. The research benefited from expert discussions at the Western Economic Association International 90th Annual Conference, on 28 June-2 July 2015, at Hilton Hawaiian Village, Waikiki, Honolulu, Hawaii, USA.

Author Contributions: Hirokazu Akahori and Yasutaka Yamamoto proposed and carried out the study. Hirokazu Akahori contributed to preparing the manuscript. Daisuke Sawauchi and Yasutaka Yamamoto participated in writing the manuscript and revising it critically. All authors have read and approved the final manuscript.

Conflicts of Interest: The authors declare no conflict of interest.

\section{References}

1. World Economic Outlook. Available online: http://www.imf.org/external/pubs/ft/weo/2015/01/ weodata/index.aspx (accessed on 1 August 2015).

2. Thomassin, P.J.; Mukhopadhyay, K. Impact of East-Asian Free Trade on Regional Greenhouse Gas Emissions. J. Int. Glob. Econ. Stud. 2008, 1, 57-83.

3. Hertel, T.W. (Ed.) Global Trade Analysis: Modeling and Applications; Cambridge University Press: Cambridge, UK, 1997.

4. Lee, H.L. An Emissions Data Base for Integrated Assessment of Climate Change Policy Using GTAP. Available online: https://www.gtap.agecon.purdue.edu/resources/res_display.asp?RecordID=1143 (accessed on 7 February 2017). 
5. Ahmed, S.A.; Rose, S.K.; Hertel, T.W.; Irfanoglu, Z.B. Development of the Version 8 Non- $\mathrm{CO}_{2}$ GHG Emissions Dataset. Available online: https://www.gtap.agecon.purdue.edu/resources/res_display.asp?RecordID= 4343 (accessed on 7 February 2017).

6. Burfisher, M.E.; Dyck, J.; Meade, B.; Mitchell, L.; Wainio, J.; Zahniser, S.; Arita, S.; Bechman, J. Agriculture in the Trans-Pacific Partnership. Available online: https:/ /www.ers.usda.gov/webdocs/publications/err176/ 49379_err176.pdf (accessed on 7 February 2017).

7. Cheong, I. Negotiations for the Trans-Pacific Partnership Agreement: Evaluation and Implications for East Asian Regionalism. Available online: https://www.adb.org/sites/default/files/publication/156283/adbiwp428.pdf (accessed on 7 February 2017).

8. Kawasaki, K. The Relative Significance of EPAs in Asia-Pacific. Available online: http://www.rieti.go.jp/jp/ publications/dp/14e009.pdf (accessed on 7 February 2017).

9. Itakura, K.; Lee, H. Welfare Changes and Sectoral Adjustments of Asia-Pacific Countries under Alternative Sequencings of Free Trade Agreements. Available online: http://www.osipp.osaka-u.ac.jp/archives/DP/ 2012/DP2012E005.pdf (accessed on 7 February 2017).

10. Lee, H.; Itakura, K. Applied General Equilibrium Analysis of Mega-Regional Free Trade Initiatives in the Asia-Pacific. Available online: http:/ /econpapers.repec.org/paper/ospwpaper/15e001.htm (accessed on 7 February 2017).

11. Petri, P.; Plummer, M.; Zhai, F. The Trans-Pacific Partnership and Asia-Pacific Integration: A Quantitative Assessment; Peterson Institute for International Economics and East-West Center: Washington, DC, USA, 2012.

12. Areerat, T.; Kameyama, H.; Ito, S.; Yamauchi, K. Trans Pacific Strategic Economic Partnership with Japan, South Korea and China Integrate: General Equilibrium Approach. Am. J. Econ. Bus. Adm. 2012, 4, 40-46.

13. Gumilang, H.; Mukhopadhyay, K.; Thomassin, P.J. Economic and Environmental Impacts of Trade Liberalization: The Case of Indonesia. Econ. Model. 2011, 28, 1030-1041. [CrossRef]

14. Liu, Z.; Mao, X.; Tang, W.; Hu, T.; Song, P. An Assessment of China-Japan-Korea Free Trade Agreement's Economic and Environmental Impacts on China. Front. Environ. Sci. Eng. 2012, 6, 849-859. [CrossRef]

15. Mukhopadhyay, K.; Thomassin, P.J. Economic and Environmental Impact of Free Trade in East and South East Asia; Springer: Berlin, Germany, 2010.

16. Saunders, C.; Wreford, A.; Cagatay, S. Trade Liberalisation and Greenhouse Gas Emissions: The Case of Dairying in the European Union and New Zealand. Aust. J. Agric. Resour. Econ. 2006, 50, 538-555. [CrossRef]

17. Verburg, R.; Stehfest, E.; Woltjer, G.; Eickhout, B. The Effect of Agricultural Trade Liberalisation on Land-use Related Greenhouse Gas Emissions. Glob. Environ. Chang. 2009, 19, 434-446. [CrossRef]

18. Akahori, H.; Yamamoto, Y. The Regional Comprehensive Economic Partnership and Its Potential Impact on Greenhouse Gas Emissions. In Proceedings of the 14th International Convention of the East Asian Economic Association, Bangkok, Thailand, 1-2 November 2014.

19. Akahori, H.; Yamamoto, Y. Does a Free Trade Area of the Asia-Pacific Increase Greenhouse Gas Emissions?: Evidence from GTAP model analysis. In Proceedings of the 11th International Conference of the Western Economic Association International, Wellington, New Zealand, 8-11 January 2015.

20. Tassone, V.C.; Wesseler, J.; Nesci, F.S. Diverging Incentives for Afforestation from Carbon Sequestration: An Economic Analysis of the EU Afforestation Program in the South of Italy. For. Policy Econ. 2004, 6, 567-578. [CrossRef]

21. Antweiler, W.; Copeland, B.R.; Taylor, M.S. Is Free Trade Good for the Environment? Am. Econ. Rev. 2001, 91, 877-908. [CrossRef]

22. Le, L.T.; van Ierland, E.C.; Zhu, X.; Wesseler, J. Energy and Greenhouse Gas Balances of Cassava-based Ethanol. Biomass Bioenergy 2013, 51, 125-135. [CrossRef]

23. Rose, S.K.; Lee, H.L. Non- $\mathrm{CO}_{2}$ Greenhouse Gas Emissions Data for Climate Change Economic Analysis. In Economic Analysis of Land Use in Global Climate Change Policy; Hertel, T.W., Rose, S.K., Tol, R., Eds.; Routledge: London, UK, 2009.

(C) 2017 by the authors. Licensee MDPI, Basel, Switzerland. This article is an open access article distributed under the terms and conditions of the Creative Commons Attribution (CC BY) license (http:/ / creativecommons.org/licenses/by/4.0/). 